Gonçalves de Magalhães and the

\title{
Gonçalves de Magalhães e \\ o sacerdócio moral do poeta \\ romântico em tempos de \\ guerra civil ${ }^{1}$
}

Romantic Poet Moral 'priesthood' in

Times of Civil War

\section{Danilo José Zioni Ferretti \\ Doutor em História Social pela Universidade de São Paulo (FFLCH/ USP-São Paulo/Brasil) e professor no Departamento de História da Universidade Federal de São João Del Rei (UFSJ - São João Del Rei/Brasil). e-mail: danilozf@ufsj.edu.br}

\section{Resumo}

0 texto discute o surgimento do romantismo brasileiro, levando em consideração sua relação com as rebeliões regenciais. Priorizando a produção de Gonçalves de Magalhães entre os anos de 1832 e 1838, destaca o aspecto de cruzada moral cristianizadora e sua relação com a auto-compreensão da missão do poeta. Discute, também, as dimensões de temporalidade inerentes à reflexão sobre a nação elaborada pelo líder romântico, destacando-se a presença da noção de palingenesia social no ambiente intelectual brasileiro da primeira metade do séc. XIX.

\section{Abstract}

This article analyses the emergence of Brazilian Romanticism, taking into account its relationship with the Regency rebellions. Prioritizing Gonçalves de Magalhães's production from 1832 to 1838, it highlights the aspect of the Christianized moral crusade and its relationship to the self-understanding of the poet's mission. It also discusses the temporality inherent in the reflection about the nation prepared by the romantic leader, highlighting the presence of the concept of social palingenesis in the intellectual Brazilian environment from the first half of XIX century.

\section{Palavras-chave}

romantismo, temporalidade, rebeliões regenciais

Keywords

romanticism, temporality, regency rebellions pela Fapemig (Universal 2008). Agradeço ainda a Larissa Raele Cestari e Luis Francisco Albuquerque de Miranda pela leitura atenta e generosa. 
2

Dentre várias outras, pode-se citar: PINASSI, Maria Orlandi. Três devotos, uma fé, nenhum milagre. São Paulo: ed Unesp, 1999; SQUEFF, Letícia. O Brasil nas telas de um pintor. Manuel de Araújo Porto Alegre (1806-1879). Campinas: ed. da Unicamp, 2004; RICUPERO, Bernardo. 0 Romantismo e a ideia de Nação no Brasil (1830-1870). São Paulo: Martins Fontes, 2004; TREECE, David. Exilados, aliados, rebeldes: 0 movimento indianista, a política indigenista e o estado-nação imperial. São Paulo: Edusp, 2008; PUNTONI, Pedro. A Confederação dos Tamoios de Gonçalves de Magalhães: a poética da história e a historiografia do Império. Novos Estudos CEBRAP, São Paulo, v.45, 1997.

LÖWY, Michel e SAYRE, Robert. Revolta e melancolia: o romantismo na contramão da modernidade. Petrópolis: Vozes, 1995.

4 PINASSI, Maria Orlandi. Op. Cit., p.153-185; RICUPERO, Bernardo. Op. Cit., p.85-111.

5

Numa análise um tanto dogmática e baseada na definição de Lucacks sobre o romantismo, Pinassi rejeita que a "essência" do programa dos letrados da revista Nitheroy fosse romântica, ainda que estes lançassem mão de "formas" românticas para melhor levar a efeito um programa, a seu ver, essencialmente vinculado à divulgação dos valores da burguesia capitalista internacional. PINASSI, Maria Orlandi. Op. Cit., p.163-164 e p.189-190. Já Bernardo Ricupero lança a questão sem, contudo, respondê-la explicitamente. 0 autor tende a caracterizar esse apego a um projeto modernizador, que identifica à noção de "civilização", mais como uma originalidade do nosso romantismo perante o europeu do que um impedimento a que seja considerado como tal. RICUPERO, Bernardo. Op. Cit., p.XXVIII.

6

BARROS, Roque S. M. de. A significação educativa do romantismo brasileiro: Gonçalves de Magalhães. São Paulo: Guijalbo, EDUSP, 1973.

\section{Introdução}

0 romantismo, no Brasil, até pouco tempo atrás, era assunto quase que exclusivo da crítica e história literárias. Várias interpretações foram elaboradas desde, pelo menos, o aparecimento das primeiras "Histórias da literatura brasileira" nas décadas finais do século XIX. Seu número é tão grande que um tratamento minimamente suficiente exigiria um texto à parte. Contudo, dos anos 1990 para cá, parece que o tema, ainda que não tenha sido muito explorado, passou a ser tratado por pesquisadores de outras áreas das ciências humanas, historiadores principalmente, que buscaram avançar abordando novos aspectos antes desprezados ou deixados em segundo plano. Essas pesquisas, frutos da afirmação da história cultural ou do crescente interesse na questão da nação (e às vezes de ambos), se baseiam principalmente em novas preocupações com o estudo das dimensões políticas e sociais da produção cultural romântica, na busca do alargamento da compreensão do movimento. ${ }^{2}$ Essas análises recentes, muitas na esteira do trabalho de Michel Löwy e Robert Sayre, tendem a considerar o romantismo mais como uma "visão de mundo" do que exclusivamente um estilo literário. ${ }^{3}$ Isso implica não só transcender a preocupação em analisar a produção dos autores românticos somente em relação a outras obras literárias, mas também em relacioná-la a um contexto político-social e a debates mais amplos e em dar destaque a outros gêneros de obras produzidas por aqueles intelectuais que não aquelas de caráter exclusivamente ficcional, ampliando o corpus documental disponivel ao analista.

Os resultados desses novos estudos são diversos, como diversas são as abordagens seguidas. No geral, parece ter havido um aprofundamento na caracterização das origens sociais e das trajetórias dos principais intelectuais, além de uma maior precisão na definição dos espaços de sociabilidade e dos grupos políticos e culturais com os quais mantiveram contato. Alguns autores apontaram inclusive o incentivo desses letrados a um programa de modernização das forças materiais do Império. ${ }^{4}$ Esse interesse ao que parece ter sido uma tentativa de inserção do Brasil nos moldes de uma modernidade capitalista levou alguns autores recentes, baseados na definição lucacksiana do romantismo como essencialmente anticapitalista, até mesmo a duvidar do caráter romântico de nossos românticos. ${ }^{5}$ Mas se a maioria não chegou a tanto, como resultado geral houve a revelação de uma maior amplitude da participação dos intelectuais românticos no universo político, social e cultural do Império, configurando um verdadeiro "programa civilizador", para além da fundamental renovação estética, já consagrada pela crítica literária e de sua "significação educativa", ressaltada pela história da filosofia brasileira. ${ }^{6}$

Mas nem tudo é inovação nos estudos do romantismo brasileiro, pois podemos notar relevantes traços de continuidade em relação a algumas análises realizadas pela crítica e história literárias. Antes de tudo, a preocupação com a inserção dos letrados românticos no universo social e político não é de todo nova, sendo um claro desdobramento de uma corrente da crítica literária preocupada com a inserção social da obra de ficção. Nesse sentido, a análise de Antonio Candido, no clássico Formação da literatura brasileira, de 1957, permanece o chão comum de onde brotam tanto os estudos mais recentes realizados pela história e crítica literárias quanto aqueles de historiadores e demais cientistas sociais que abordamos acima. Também de Antonio Candido os atuais estudos preservaram a 
7

Para Antonio Candido, a religiosidade do primeiro romantismo é entendida como um elemento estético voltado a combater o paganismo do neoclassicismo. 0 autor vai além e busca diferenciar as manifestações entendidas como fruto de uma fé pessoal daquelas resultantes de uma inclinação do romantismo europeu a valorizar a "religiosidade", como "abertura da sensibilidade para 0 mundo", independente de sua forma ser cristã ou não. Vista como elemento estético, propensão individual dos autores ou traço meramente importado do romantismo europeu, a religiosidade foi deixada em segundo plano. CANDIDO, Antonio. Formação da literatura brasileira. Vol.02. Belo Horizonte: Itatiaia, 2000. p.17-18. Já Maria Orlanda Pinassi chega a considerar a possibilidade de a religiosidade, no projeto romântico brasileiro, servir como antídoto ao conflito social, mas logo descarta essa hipótese (p.162). Mesmo se inova ao conferir centralidade ao cristianismo no projeto romântico, tende a considerá-lo (na esteira de uma subjacente concepção de ideologia como falsa consciência) como mero encobrimento falseador dos conflitos de classes inerentes à sociedade capitalista que, em última análise, os românticos buscavam construir no Brasil (p.195196). Bernardo Ricupero aponta a preocupação de nossos românticos com a manutenção da ordem social, mas não a relaciona com a recuperação da religião que não é problematizada em seu estudo concentrado na questão da nação e originalidade literária. Ainda que reconheçamos a importância do modelo francês, procuramos, aqui, mostrar o contexto social brasileiro que deu novo sentido e importância a essa "importação".

8

DOSSE, François. La marche des idées. Histoire intellectuelle et histoire des intellectuels. Paris: La Découverte, 2003. p.25-32.

9

Para um quadro pormenorizado da trajetória inicial dos românticos e sua relação com o liberalismo moderado, ver PINASSI, Maria Orlandi. Op. Cit., p.27-43. centralidade conferida ao tratamento da questão nacional e uma forma específica de abordá-la.

Permanece, ainda hoje, uma caracterização do coração do projeto romântico como tendo sido de promover a independência cultural do país por meio da criação de uma literatura própria, que expressasse a realidade nacional e desse forma ao sentimento de brasilidade. Nesse quadro interpretativo, tende-se a destacar a relação do romantismo com o movimento da independência e a aversão ao elemento lusitano como sendo os fatores contextuais que orientam a elaboração das obras do grupo. Também se ressalta o papel de alguns intelectuais europeus (Ferdinand Denis e Almeida Garrett, principalmente) na definição inicial dos critérios de uma brasilidade literária e como o movimento encontrou seu verdadeiro manifesto no texto "Discurso sobre a história da literatura do Brasil", de autoria de Gonçalves de Magalhães, publicado em 1836 na revista Nitheroy, editada em Paris.

Seguramente, tratam-se de elementos importantes na definição do programa do grupo. Mas acredito que não correspondem a todo o cerne do programa, que existe outra dimensão, tão central quanto a de criar uma literatura nacional (e a ela relacionada), na reflexão romântica sobre a nação e, por consequência, no programa de toda a geração, que merece ser alçada ao centro de nossas considerações. Refiro-me à dimensão de cruzada moralizadora com caráter religioso de nossos primeiros românticos, que se não deixa de ser considerada, nas análises, como aspecto relevante, nunca assume a centralidade que tinha para os contemporâneos nem tem merecido tentativas de explicação satisfatórias. ${ }^{7}$

Dois problemas, portanto, orientam o presente texto. 0 primeiro é a tentativa de destacar o aspecto de cruzada moral cristianizadora que orientou essa "primeira geração". O segundo é a busca de compreender, à luz da reflexão de Reinhard Koselleck, as dimensões de temporalidade inerentes à concepção de nação elaborada por nossos românticos. Para tanto, me concentrarei preferencialmente, mas não exclusivamente, na figura de Gonçalves de Magalhães, não somente por ter sido tomado pelos contemporâneos como o líder e principal referência do movimento romântico brasileiro, mas também por ter desenvolvido, talvez como nenhum outro autor, a reflexão sobre o status temporal da nação brasileira e a missão moral e religiosa do poeta romântico. Em vez de abordá-lo exclusivamente como literato ou filósofo, ele será aqui analisado antes como intelectual, como um agente que tem como função social autoproclamada e reconhecida a elaboração simbólica ${ }^{8}$, e que se imiscui nas questões públicas por meio de várias atividades, sendo as principais, no caso, a da produção literária e filosófica, sempre exercidas de forma interdependente.

\section{0 diagnóstico romântico: Brasil, nação em decomposição}

Diferente do romantismo francês, que surge da confluência de duas vertentes, uma ultrarrealista (católica e legitimista) e outra liberal, o brasileiro surge das fileiras dos grupos liberais. Mais especificamente, do liberalismo moderado, como têm ressaltado vários estudos. ${ }^{9}$ Desse grupo, nossos jovens românticos (Araujo Porto Alegre, Gonçalves de Magalhães, Francisco de Salles Torres Homem), antes de sua ida à Europa, estavam mais próximos das figuras de Evaristo da Veiga e do padre mestre Francisco de Monte Alverne. Este fora professor de Porto Alegre e Gonçalves de Magalhães no 
10

MOREL, Marco. As transformações dos espaços públicos. Imprensa, Atores Políticos e Sociabilidades na Cidade Imperial (1820-1840). São Paulo: Hucitec, 2005. p117-127.

11

Ver, principalmente: "Primeira ode pindárica ao glorioso dia sete de abril", "Segunda ode pindárica ao glorioso dia sete de abril", "Ode ao glorioso dia sete de abril", "Ode ao dia 25 de março de 1831. Aniversário do juramento da Constituição do Império", "Soneto improvisado em uns outeiros", "Ode à Liberdade. Feita antes da Revolução de Sete de abril" In: MAGALHÃES, D. J. Gonçalves de. Poesias. Rio de Janeiro: Typografia de R. Ogier, 1832

12

"Ode ao glorioso dia sete de abril". In: MAGALHÃES, D. J. Gonçalves de. Op. Cit., p.19. 13

"Ode à Liberdade. Feita antes da Revolução de Sete de abril". In: Ibidem, p.27.

14

"Segunda ode pindárica ao glorioso dia sete de abril". In: Ibidem, p.17.

15

"Primeira carta". In: PORTO ALEGRE, M. A. e MAGALHAES, D. J. Gonçalves de. Cartas a Monte Alverne. São Paulo: Conselho estadual de cultura, Imprensa Oficial, 1964. p.15.

16

PORTO ALEGRE, M. A. "Contornos de Nápoles". Nitheroy, Paris, vol.2, p.177.
Seminário de São José, no início da década de 1830, onde Ihes apresentou os rudimentos da filosofia eclética. Parece ter apresentado a ambos uma retórica que misturava o elogio das instituições liberais a uma preocupação especial com a valorização do catolicismo como antídoto à dissolução social e à "hidra da anarquia", calcada na leitura de Chateaubriand, bastante precoce no meio brasileiro. Assim, antes mesmo de partirem para a Europa, os futuros românticos já continham alguns valores forjados em um meio liberal moderado que buscava finalizar a revolução de $1831 .{ }^{10} 0$ interessante é que nesses primeiros anos da década de 1830, quando ainda pairava a ameaça de restauração absolutista, a ênfase recaía sobre a afirmação do princípio de liberdade.

Essa propensão inicial ficou patente nas primeiras poesias publicadas por Gonçalves de Magalhães, ainda em 1832. A crítica tende a destacar a submissão aos princípios da estética neoclássica, quando podemos também perceber a centralidade de temas políticos, com destaque para a exaltação da pátria e da liberdade em sua luta vitoriosa contra a tirania. ${ }^{11}$ São poesias de pouca qualidade, mas, escritas no calor da hora, são significativas do entusiasmo de Magalhães com a abdicação de D. Pedro I, entendida como a aurora definitiva da liberdade brasileira: "Minh'alma se dilata/ Pelo imenso salão da Eternidade,/ E a meus olhos se mostram/ As portas do Futuro escancarada/.../Ó Pátria! Ó Pátria minha!/ Raiou de novo o dia venerando/ da tua liberdade"12. Como percebemos, o 7 de abril dilatava o horizonte de expectativa desses jovens e projetava um futuro radiante de liberdade nacional. Então, a missão central do vate era "mil encômios tecer à Liberdade"13, que tinha como ameaça maior o "despotismo" dos reis. Ainda que a liberdade receba todas as glórias e o tom seja de entusiasmo, ao final de uma das poesias, o gênio do Brasil a todos exortava que pusessem fim aos conflitos e consolidassem a obra realizada: "Eia, de vós se apartem/Os ódios, as discórdias, e as vinganças/.../ União, União, vos cumpre agora/ Só união da queda a pátria escora"14.

Esse ambiente de entusiasmo se alteraria ao longo dos anos 1830, à medida que a situação interna do Brasil tornava-se mais tensa. Da Europa, um sinal de apreensão já podia ser encontrado na primeira carta que Araujo Porto Alegre enviou para Monte Alverne, em 1832. Nesse ano, em que a cidade do Rio de Janeiro foi marcada por um sem número de levantes de "tropa e povo", de Paris, o pupilo afirmava ao mestre pretender "o mais cedo possivel abraçá-lo, lançar-me no seio de meus patrícios; e se a ambição, esse abutre que rói as entranhas da sociedade, não tiver lançado por terra os laços que unem o Brasil"15.

Quando foi publicada a Nitheroy, em 1836, os conflitos no Pará e no Rio Grande do Sul já vigoravam. A eles se transportava a imaginação dos nossos vates, quando contemplavam as ruínas do mundo clássico e as belezas naturais da Itália, imprimindo um sentido original e trágico à sua versão brasileira de grand tour. A natureza dos arredores de Nápoles inspirava, em Porto Alegre, angústias com o futuro da pátria: "A Solfatara (vulcão semiextinto) é a verdadeira imagem de uma nação que luta em guerras intestinas; é a imagem da nossa Pátria, que fumega sangue nas duas extremidades e ameaça no centro uma erupção terrivel que talvez a desmembre para sempre. Deus nos proteja!"16. Nota-se a referência clara à Farroupilha e à Cabanagem, revoltas ocorridas "nas duas extremidades", a meridional e a setentrional, respectivamente. 

Poéticos e Saudades. Rio de Janeiro / Paris: Casa de João Pedro da Veiga / Dauvin et Fontaine, 1836. p.249.
A questão não deixou de ser elaborada poeticamente. 0 mesmo temeroso Porto Alegre, nos rastros de um Verney nunca citado, elaborava, ao seu modo, o topos romântico da reflexão sobre o fim dos impérios diante das ruínas do mundo antigo. Diante do que restou da romana Cumas, fazia aparecer três espíritos, apresentados como responsáveis pela destruição dos impérios: "Tirania dos Reis", "Egoísmo dos humanos" e - o pior de todos - "Guerra Civil"17. As lições da antiguidade eram direcionadas para a nação nascente que, se quisesse se afirmar como vigoroso Império tropical, teria que todas as três evitar.

Em chave menos pessimista, mas ainda igualmente alarmada, Gonçalves de Magalhães invertia a tendência de enviar suspiros de saudade da Europa para a Pátria e passava a expressar poeticamente os suspiros que o Brasil conflagrado enviava à Europa. Na poesia "Os Suspiros da Pátria", publicada em 1836, questionava:

Mas, oh, Pátria, quem causa mágoas tuas?/Ah! Não fales, não digas... sofre.... espera./ Eu conheço teu mal. Ah! não são estes,/qu inda os pulsos têm lívidos dos ferros, / recém-livres, costumes têm de escravos,/ estes não são, que ao teu porvir brilhante/as portas abrirão; são os seus filhos./Espera, espera, que o porvir é grande;/ e a vontade do Eterno, que os teus montes,/o teu céu, os teus rios nos revelam,/será cumprida um dia: espera, espera./Ainda ontem te ergueste de teu berço;/ mal um passo ensaiaste,/ e não é crível que amanhã já morras. (grifos meus). ${ }^{18}$

Ainda tateante diante de um fenômeno inédito, a poesia indicava uma primeira tentativa de explicar os conflitos emergentes como resquícios da antiga ordem, como resultado da ação de uma velha geração desacostumada à liberdade e ainda atada ao fardo da "escravidão" colonial. Nota-se certa indecisão quanto à situação temporal da nação brasileira: ela estaria na aurora de uma longa e promissora existência, ou em seu ocaso? MagaIhães buscava, a todo momento, exorcizar a possibilidade de que a nação, recém-nascida, já se direcionasse para sua morte. Para tanto, reforçava a expectativa de um futuro livre e lisonjeiro, apelando ainda para a ideia de uma predileção divina pelo Brasil, evidenciada na pujança da natureza com que fora dotado. Mas o dado dramático era a latente ameaça da aniquilação precoce da nação.

A permanência dessa expectativa de um futuro promissor seria fortemente comprometida com a multiplicação e o agravamento dos conflitos. Nesse sentido, os anos de 1837 e 1838 parecem ter aumentado o temor e redirecionado as reflexões de nossos românticos. À continuidade da Farroupilha e da Cabanagem nos extremos do Império, juntou-se a Sabinada, controlando, por quatro meses, a segunda maior cidade do país e reavivando temores de novo levante escravo em Salvador. Esse ambiente de incerteza pode ser percebido nas páginas do Jornal dos Debates Políticos e Literários (JDPL), periódico editado pelos românticos entre aqueles anos e responsável por manter a articulação do grupo quando da sua volta ao Rio de Janeiro no início de 1837. Inexplicavelmente, até hoje, o jornal tem sido desprezado pelas análises sobre o romantismo, de forma que sobre ele nos debruçaremos.

Com a missão explícita de derrubar a regência Feijó, dentre outras coisas pela acusação de incapacidade de pôr termo à guerra civil, o Jornal dos Debates, sob a redação de Salles Torres Homem (durante o ano de 1837) e Pereira da Silva (1838), publicou uma série de artigos de Gonçalves de Magalhães. Seu objetivo central era a tentativa de tornar inteligivel a crise por que passava o Brasil e indicar alternativas de reversão. 
19

KOSELLECK. Reinhart. 'Espaço de experiência' e 'horizonte de expectativa': duas categorias históricas. In: __. Futuro Passado. Contribuição à semântica dos tempos históricos. Tradução Wilma Patricia Maas, Carlos Almeida Pereira. Rio de Janeiro: Contraponto, Ed. PUC-RIO; 2006.

20

M. História do Brasil, desde a chegada da Real família de Bragança, em 1808, até a abdicação do Imperador D. Pedro I, em 1831, por João Armitage. Traduzida do Inglez, por um Brasileiro. Vende-se em casa de Villeneuve e C. Jornal dos Debates Políticos e Literários, Rio de Janeiro, n.07, 23/05/1837.

21

KOSELLECK. Reinhart. Historia Magistra Vitae Sobre a dissolução do topos na história moderna em movimento. In: Op. Cit.

22

ARAUJO, Valdei Lopes. A experiência do tempo. Conceitos e Narrativas na Formação Nacional brasileira (1813-1845). São Paulo: Aderaldo \&t Rothschild, 2008. p.119-133.
Entremeados a notícias exasperantes sobre derrotas das forças legalistas, saques de cidades pelos rebeldes no Rio Grande do Sul e ataques de rebeldes sabinos na Bahia, os artigos de Magalhães se destacavam pelo peso que passaram a conferir à história. Diante de um presente agônico, em que as antes otimistas expectativas de um futuro de liberdade nacional tornavam-se duvidosas e se embaralhavam, Magalhães indicava no estudo do passado a melhor forma de procurar reabrir os caminhos do porvir, ou mesmo de identificar a possibilidade de um porvir para a nação. Ou, em termos koselleckianos, diante das incertezas do presente, buscava avaliar a possibilidade de um horizonte de expectativa mediante a avaliação de experiências passadas. ${ }^{19}$ No centro de sua reflexão, a questão da temporalidade assumia um lugar de destaque, estruturando a própria elaboração de um diagnóstico da nação. Em uma resenha de História do Brasil de Armitage, de maio de 1837, afirmava a importância da história para sondar a "sorte dos Impérios":

\begin{abstract}
Se há um estudo próprio a todas as capacidades, em que todas as inteligências podem colher úteis e importantes lições, sobre a ordem providencial das coisas humanas é sem dúvida alguma o estudo da História. (...) Seria um grave absurdo acreditar-se que uma estúpida fatalidade, ou meras combinações dos homens, decidem da sorte dos Impérios. A não considerar a história somente por esse lado filosófico, já deveria ela merecer toda a importância científica de uma meditação que, exaltando o nosso espírito, nos põe em estado de julgar da nossa missão terrestre. Mas ao lado desta parte especulativa, quantas lições práticas não podemos tirar? Quantas aplicações não podemos fazer? A imagem do passado, assim presente a nossos olhos, nos mostra os tropeços da estrada, e nos ensina a evitar duvidosas e arriscadas experiências. (grifos meus). ${ }^{20}$
\end{abstract}

À visão de um repertório de exemplos limitados e fixos de condutas a se imitar, típicas da antiga concepção da história como magistra vitae aqui presente, mas em fase de dissolução - o poeta prefere adotar nova concepção. Ela tenderia a retirar lições das experiências que constituem o conjunto do processo histórico, identificado com um plano providencial que o poeta busca desvendar em seus traços principais. ${ }^{21}$

Podemos perceber que os artigos de 1837 do Jornal dos Debates dão prosseguimento à reflexão que Magalhães iniciara no ano anterior na Nitheroy sobre a história da nação, principalmente no Ensaio sobre a História da literatura no Brasil. Conforme já ressaltado por Valdei Lopes de Araujo, com esse artigo Magalhães introduzia, no Brasil, o moderno conceito de história, marcado pela predominância da linearidade progressiva, ainda que não de todo isenta de articulação com alguns elementos cíclicos secundários. Foi exatamente essa percepção predominantemente linear que permitiu a afirmação de um certo otimismo e alguma segurança por criar um futuro visto como qualitativamente diferente do passado colonial e autônomo em relação ao passado de Portugal. ${ }^{22} 0$ que percebemos é que esse certo otimismo que Valdei Araujo identifica na reflexão de Magalhães foi sendo paulatinamente solapado pelo dramático contexto de seu presente e pelas dúvidas que se acumulavam sobre a possibilidade de efetivação daquela antiga expectativa de construir uma nação livre.

A prioridade passava, então, a ser o confronto do caso brasileiro com as experiências de outros povos, para tentar identificar o status temporal da nação e o caminho a se evitar ou a se seguir no futuro. Nesse trabalho, 
M."Movimento de decomposição do Brasil". Jornal dos Debates Políticos e Literários, Rio de Janeiro, 01/07/1837. uma primeira reação de Magalhães parece ter sido de desorientação. Num primeiro momento de sua reflexão, nenhuma experiência passada parecia ser capaz de lançar luz sobre o caso brasileiro.

Em artigo sugestivamente intitulado "Movimento de decomposição do Brasil", de julho de 1837, recorria, inicialmente, à experiência dos impérios da antiguidade, neles identificando uma dinâmica marcada pela "ideia de que as nações, como os homens, têm sua infância, sua época de maturidade e de virilidade, sua velhice, e sua morte. É um fato histórico das nações antigas, e desta lei não escapou o colosso romano"23. Essa concepção cíclica, regida por referenciais de uma temporalidade natural pautada pela constante sucessão de estágios de geração, crescimento, degradação e morte - era restrita às sociedades do mundo antigo, não tendo mais validade no presente, uma vez que " 0 que dizemos dos antigos povos não se pode bem aplicar aos modernos (...)". Portanto, ela pouco orientava a nação brasileira.

Quanto às nações modernas, Inglaterra e França, haviam rompido com o paradigma cíclico das nações antigas por intermédio exatamente das experiências revolucionárias por que passaram. "Considerando a história ensanguentada de Inglaterra, desde o infeliz Carlos I até o tirano Jacques II, todos os horrores da sua revolução, quem seguindo o exemplo da história antiga, deixaria de crer que a Inglaterra ia tocar o seu termo? Entretanto ela saiu mais bela, e todos os dias remoça!" 0 mesmo teria ocorrido com a revolução francesa, "esse movimento de completa destruição", em que as expectativas de aniquilação da nação francesa reverteram em seu exato contrário, uma vez que "a França ergueu-se, valendo mais do que valia, mais forte do que nunca". A partir desses casos paradigmáticos, Magalhães avançava uma caracterização da dinâmica histórica linear e progressiva, comum às nações modernas, afirmando que "a velhice dessas grandes nações não está diante delas. A velhice das nações é a corrupção e a fraqueza, e elas a deixaram após si, e todos os dias remoçam e se regeneram"24.

Teoricamente, ao se orientar por essas experiências de renovação, o Brasil poderia sentir-se aliviado, pois a atribulação dos conflitos em que vivia poderia ser somente a véspera de um salto qualitativo. Mas nem mesmo essa dinâmica dos povos modernos era, naquele momento, considerada por Magalhães como compatível com o que observava no Brasil. Mais do que nos guiarmos pelo caminho do progresso europeu, dele tudo nos afastava e diferenciava. "Assim, nós observamos dois fatos na história da civilização moderna; um de regeneração, e de edificação, como apresentam hoje a França e a Inglaterra; outro critico, e de decomposição, como 0 Brasil está mostrando."25

Magalhães apresentava o diagnóstico da situação brasileira como sendo um original e angustiante estado de "decomposição", em tudo diferente daquilo que se observava na Europa, no passado e no presente. Por sua descrição, haviamos saído do caminho que nos conduziria à civilização, só nos restando a certeza da falta de experiências anteriores comparáveis:

Nós nos achamos em uma crise. Todos a conhecem, todos clamam e se lastimam (...) Entretanto, esse estado não pode durar; época de transição deve deparar em alguma coisa. (...) Onde iremos parar? 0 que seremos amanhã? Verdadeiros problemas que ninguém pode responder. 0 aspecto de nossa crise é singular, e nem achamos exemplos, a menos que os não procuremos na decadência do império bizantino, nessa corrupção, venalidade e baixeza da Corte do oriente. ( grifos meus). ${ }^{26}$ 
M. "Estado Crítico do Brasil". Jornal dos Debates Políticos e Literários, Rio de Janeiro, n.19, 08/07/1837.

28

TREECE, David. Exilados, aliados, rebeldes: o movimento indianista, a política indigenista e 0 estado-nação imperial. São Paulo: Edusp, 2008. p.156-159.

29

"Comunicado. Ao Correio Oficial e ao Cronista." Jornal dos Debates Políticos e Literários, Rio de Janeiro, 01/fev/1838. 0 artigo é assinado por X.X., que pelo teor filosófico da argumentação, pela recorrência a temas anteriormente tratados, dificilmente seria de autoria de outro dos pouquíssimos colaboradores do jornal que não Magalhães. Vale lembrar que a grande maioria dos artigos do jornal não era assinada, sendo da lavra do editor. Os poucos assinados o eram por um restritíssimo número de colaboradores, destacando-se como o mais prolifico Magalhães que, se em 1837, assinava M., passou a assinar X.X. em 1838
A ausência de exemplos impossibilitava encontrar respostas para a situação brasileira, outro indício de que, para Magalhães, havia um distanciamento entre o campo de experiência e o horizonte de expectativa. As experiências passadas - excetuando-se a pouco lisonjeira do império bizantino, que nenhuma atenção recebeu do autor - poucas luzes lançavam sobre o futuro. Nos artigos, notamos um Magalhães tateante, em processo de reelaboração de seus referenciais temporais, não poucas vezes incorrendo em contradições. Recusando o ciclo dos antigos e o progressismo linear pela revolução dos modernos, o Brasil parecia apresentar uma terceira via de dissolução, cujo desdobramento futuro era ainda incerto. A própria nação parecia carecer de peculiaridades diante da situação calamitosa:

\footnotetext{
"Diz o grande Muller que, na história de cada povo, deve-se considerar a parte em que ele se distingue. (...) Isso posto, o que devemos nós considerar do Brasil? 0 que representa ele? Que lição importante e histórica podemos colher da nossa época? Que face notável apresenta? Como caminha! Donde vem? e para onde vai ele? Nem marinha, nem indústrias, nem artes, nem liberdade moderada, nem excessiva, nem arte militar. Nada, enfim... Completa decomposição!
}

Eis aí o único objeto que deve atrair a nossa atenção. A decomposição é um estado natural como a organização, somente seu aspecto é horrivel, imoral, irreligioso, e corrupto: é o estado precursor da morte para as nações, se pode haver outra morte para as nações, que não seja esse mesmo estado de abjeção." (grifos meus). ${ }^{27}$

0 poeta, transformado em profeta, dedicava-se a caracterizar a crise de decomposição. Apresentava a imagem de um Brasil disforme, sem caráter definido, degradado, sem contribuição significativa à civilização. Mas revelava, principalmente, o medo da morte da nação nascente que, vimos acima, Magalhães procurava exorcizar na poesia "Os suspiros da Pátria", de 1836, mas que, um ano depois, impunha-se como uma possibilidade iminente e indisfarçável. Magalhães, ainda que nesse ponto tenha sido muito mais comedido que o catastrófico Gonçalves Dias ${ }^{28}$, resvalava em prognósticos apocalípticos sobre o futuro nacional, ao sugerir a possibilidade de sua aniquilação.

Tornando a situação um tanto paradoxal, Magalhães considerava que o início de todo o processo de decomposição remetia ao momento posterior ao movimento da Independência, que teria sido o marco de nascimento da nação como corpo político autônomo: "a revolução é uma e ela mesma começa depois da independência, continua ainda; a geração que a saudou, ao entrar na carreira da vida, não verá talvez seu termo" (grifos meus). ${ }^{29}$

Percebe-se que, a todo momento, o poeta, sondando os tempos passados e perscrutando o futuro, tem dificuldade em definir o status temporal da nação brasileira, traçando um quadro em que se destaca uma tensão constante entre duas ideias: a de que seria uma nação em seu nascimento, apontando para uma temporalidade linear progressista e por isso potencialmente otimista com o futuro, e a de que seria uma nação em decomposição, recorrendo a uma visão que fechava a possibilidade de um futuro promissor. Mas Magalhães já havia apresentado uma forma própria de encaminhamento dessa tensão nesses anos finais da regência. Ao dar continuidade ao debate com os jornalistas governistas, atingia um ponto estável na precisão de seu diagnóstico. Buscando uma centelha de esperança, discutia sobre os desdobramentos possíveis para o estado de decomposição do país e questionava: 
Interior. Ao Correio Oficial e o Cronista, por X.X. Jornal dos Debates Políticos e Literários, Rio de Janeiro, n.55, 16/02/1838.
Nessa obra de 1769, o naturalista buscava apresentar uma explicação de como a estrutura dos seres era preservada e transmitida ao longo do tempo. Formulava um dispositivo de evolução marcado pelo desenrolar de estruturas préformadas existentes como sementes em cada ser. A partir de sucessivas catástrofes naturais, essas estruturas se desdobravam em formas novas, que correspondiam a um estágio superior previamente definido que aproximava da perfeição divina toda a cadeia dos seres. Assim, suprimia-se palingeneticamente as formas antigas por novas, mas sem variação efetiva, pois tudo estava predeterminado como meio de superar progressivamente os efeitos da Queda. Caudatário de uma concepção teológica de evolução, Bonnet buscava conferir uma explicação natural à ressurreição, conciliando relato bíblico e as ciências naturais setecentistas, sem deixar de incluir um toque de otimismo leibniziano, uma vez que toda a destruição era entendida como um dado positivo, sendo condição para efetivação do plano da salvação. McCALLA, Arthur. Palingénésie philosophique to Palingénésie sociale: From a Scientific Ideology to a Historical Ideology. Journal of the History of Ideas. vol 55, n.3, jul.1994. Consultado em http://www.jstor.org/ stabel/2709848, acessado em 19/02/2010.

32

Para o caso francês e a busca de inteligibilidade da revolução, há traços da noção palingenética nas obras de autores católicos como De Maistre, Chateaubriand e Lamartine, além do já citado Ballanche. Ver McCALLA, Arthur. A Romantic Historiosophy. The Philosophy of History of PierreSimon Ballanche. Leiden, Boston, Köln: Brill, 1998. Agradeço a Angélica Loureiro por ter-me, de Londres, disponibilizado esse livro.

33

Sobre o neocatolicismo em geral e a obra de Ballanche, ver BENICHOU, Paul. Romantismes français 1. Le sacre de l'ecrivain. Le temps des prophetes. Paris: Gallimard Quarto, 2004. p.152166 e p.511-540.
Qual é o meio de transição das épocas de decomposição para as épocas orgânicas?

A história do passado pode resumir-se nesta lei, que os povos não regeneram-se senão depois de terríveis oscilações, de profundas desordens. A crise é substituída pela organização, mas entre a degradação e a reabilitação interpõe-se a época da expiação dos sacrifícios e das vítimas. 0 dogma cristão da queda e redenção do homem é uma expressão religiosa da lei universal que preside ao desenvolvimento humanitário. Sempre que há desorganização, há gerações redentoras, isto é, gerações que servem de vítimas no grande sacrificio para reabilitação das gerações futuras. A lei filosófica da perfectibilidade confunde-se com este dogma do cristianismo para formar a palingenesia social, o mais transcendente ponto de vista da especulação. Feliz o amigo dos homens que aspira a ser vítima e não sacrificador nesses holocaustos de sublime horror! (grifos meus). ${ }^{30}$

Finalmente, seu esforço desembocava na definição de uma "lei história" que seria a chave de seu diagnóstico da nação: a lei da palingenesia social. Essa constituía uma certa concepção de tempo definida pela sucessão de morte (individual ou coletiva) e renascimento, em que a violência da catástrofe (natural ou social) é entendida como um momento necessário para a regeneração, em que a morte é condição para que haja nova vida. Comum a muitas sociedades pré-modernas, não sendo de forma alguma estranha à própria tradição cristã, a palingenesia não deixou de desempenhar também papel importante no nascimento da ciência europeia desde o séc. XVI até o XVIII, quando recebeu o mais acabado tratamento pelas mãos do naturalista suiço Charles Bonnet e sua Palingenesie philosophique. ${ }^{31}$

Mais próximo de nosso contexto, o romantismo, principalmente 0 francês, parece ter se apropriado do conceito e readequado ao universo da sociedade e da história para dar inteligibilidade e aceitação à violência da Revolução francesa. ${ }^{32}$ A referência maior foi a obra do pensador neocatólico Pierre Simon Ballanche, figura de relativa importância no universo intelectual francês que, a partir de 1822, redefiniu em termos de filosofia da história a reflexão de Bonnet e elaborou uma vasta obra intitulada exatamente Palingenesie sociale, onde Gonçalves de Magalhães parece ter se inspirado, uma vez que adota o nome exato da teoria. Por ela, Ballanche buscava realizar a síntese, característica do neocatolicismo francês de início do séc. XIX, entre o dogma cristão e os novos valores do progresso e da liberdade. ${ }^{33} \mathrm{E}$ o fazia mediante a elaboração de uma filosofia da história própria, em que procurava explicar a evolução de toda a humanidade por meio de um plano Providencial marcado pela sequência necessária entre morte e ressurreição das sociedades. 0 papel renovador dos cataclismos naturais em Bonnet passava a ser desempenhado, em Ballanche, pelas revoluções e comoções sociais, que tinham sua negatividade atenuada ao serem interpretadas como partes de um plano providencial visando um aperfeiçoamento social predeterminado que anularia os defeitos inerentes à Queda pelo pecado original, e aproximaria a Humanidade de Deus.

A teoria da palingenesia social assumia aspectos de uma teodiceia romântica que explicava o sofrimento e o sacrifício como inerentes ao progresso humano, sem retirar-lhe o tradicional caráter expiatório, de punição divina por faltas coletivas. Ela também implicava a conciliação de elementos estáticos e transitórios da condição humana, pois, ao mesmo tempo em que admitia a mudança pela evolução das capacidades espirituais do Homem, essa transformação era entendida como mero 
34

McCALLA, Arthur. Palingénésie philosophique to Palingénésie sociale...Op. Cit.

"Interior. Estado crítico do Brasil" por M. Jornal dos Debates Políticos e Literários, Rio de Janeiro, n. $19,08 / 07 / 1837$

36

"Interior. Ao Correio Oficial e o Cronista" por X.X. Jornal dos Debates Políticos e Literários, Rio de Janeiro, n.55, 16/02/1838. desdobramento de uma essência humana pré-existente. Mas que não se realizaria somente por meio da intervenção providencial, pois Ballanche mantinha um espaço da liberdade da ação humana na definição do curso da história, ou seja, era necessário que as sociedades buscassem seu aperfeiçoamento, sempre entendido no sentido de uma crescente espiritualização de todas as classes sociais. ${ }^{34}$

Os efeitos heurísticos da "Palingenesia Social" de Ballanche, para Magalhães, são bastante claros. Imediatamente, ela possibilitava resolver a aparente aporia de seu pessimista diagnóstico temporal da nação, pois, sem negar o que parecia ser uma incontestável dissolução ou morte, abria a possibilidade lisonjeira de uma regeneração. Nesse sentido, reabria a possibilidade de um futuro para a nação, descortinando novamente um horizonte de expectativa a se definir. Não foram poucas, de fato, as observações esperançosas de Magalhães, ainda que prevalecesse uma angústia com a necessária prova da violência que sua geração teria que passar. Afinal, "A regeneração é para os povos, o que a imortalidade além-túmulo é para o homem. Ambas as ideias são consoladoras, mas o ponto crítico da passagem é terrivel, e amedronta. A lição solene da história, que nos diz que é necessário que a geração velha e corrupta ainda mais se corrompa, e desapareça (...), é uma lição que faz tremer, e nos infunde n'alma uma pavorosa melancolia. 0 que fizemos para que essa calamidade sobre nós caia na época em que vivemos? 0 que fizemos a Providência o sabe ${ }^{135}$. Claro aparece aqui o sentido expiatório da noção de Palingenesia social, que convivia com expressões de esperança.

A noção também dava uma forma específica à perspectiva temporal de Magalhães que, conforme já identificado por Valdei Araujo, conjugava linearidade progressiva com elementos cíclicos. Pois, se a história é entendida como seguindo um padrão cíclico regular de decomposição seguida de regeneração, essa última se dava em um patamar superior, implicando um claro aperfeiçoamento, uma vez que, para Magalhães, "a Humanidade é essencialmente progressiva, como o anjo do Apocalipse, ela também não pode ter descanso na sua viagem para o Sinai desconhecido do porvir: uma voz misteriosa Ihe grita constantemente do fundo do coração - Marcha, marcha." ${ }^{36}$ Esse irresistivel movimento permitia a combinação, pela noção da palingenesia, do progressismo linear e da recorrência cíclica, abrindo a possibilidade de vislumbrar um futuro em que, das cinzas de um Brasil dilacerado pela guerra civil nasceria uma nação purificada, em um estágio superior. Recuperava, assim, a noção de "regeneração", dotando-a de um novo sentido compatível com a noção de tempo linear progressista.

Mas a importância da teoria da palingenesia social está para além do oferecimento de uma inteligibilidade e orientação para o contexto das rebeliões regenciais. Pois ela parece ter configurado uma chave explicativa do processo formativo da nacionalidade que vai fazer escola no romantismo brasileiro. Ela talvez possa ser identificada com uma temporalidade propriamente romântica, usada para explicar a formação nacional brasileira, estando presente nas principais tentativas de dar configuração literária à nação. Ela parece já ter orientado a própria forma como Magalhães estruturou a narrativa de $A$ Confederação dos Tamoios, sua obra maior, poema épico cuja concepção remonta ao ano de 1839 e que foi publicado em 1856. Nele, Magalhães poetizou o sacrifício do herói indígena Aimbirê, sacrifício pranteado, pois cometido pelas forças cruéis da colonização, mas, 
37

TORRES HOMEM, F. S. "Introdução. Progressos do século atual". Revista Minerva Brasiliense, Rio de Janeiro, n.01, 01/11/1843, p.VI.

38

TREECE, David. Op. Cit. p.154-178.
DIAS, Gonçalves. "Resposta a 'Religião'". Guanabara, Rio de Janeiro, n.4, maio 1850, p.130-131. ao mesmo tempo, visto como necessário para a fundação da cidade de São Sebastião do Rio de Janeiro, apresentada como sinédoque da nova colônia, que, por sua vez, representava a nova fase necessária e avançada - pois cristã - da formação nacional. 0 sacrifício do Tamoio, vítima inocente, aparecia, assim, como a dramatização de um momento-chave na transição palingenética para a formação nacional.

De Magalhães, a noção parece ter passado para seu amigo Torres Homem. No texto introdutório ao primeiro número da revista Minerva Brasiliense, de 1843, esse autor assim concluía seu voo panorâmico sobre os "progressos do século atual":

Parece que, na ordem providencial do mundo, nada se obtém sem sacrificio; ele é a condição de nossa perfectibilidade; para que tenha lugar o progresso da espécie, é mister que uma geração seja oferecida em holocausto a outra; e assim o desenvolvimento das sociedades oferece 0 aspecto de uma redenção contínua, segundo essa lei, que um filósofo cristão dos nossos dias chamou - paingenisica (sic). ${ }^{37}$

0 trecho interessa não somente por remeter a Ballanche - o "filosofo cristão dos nossos dias" - mas também por revelar o potencial de divulgação da ideia pela sua publicação em texto-chave de uma das principais iniciativas editoriais românticas. Publicado na Minerva, a noção teria divulgação segura entre o meio literário.

De forma mais velada, a noção parece também ter tido alguma presença na obra poética e ensaística de Gonçalves Dias, ainda que Ballanche nunca seja citado. Como já apontou David Treece, o poeta dos Timbiras era marcado por uma visão apocalíptica da história. ${ }^{38}$ Mas o que Treece não indica é que o apocalipse gonçalvino contemplava a possibilidade de um renascimento, como atestam as poesias "A Tempestade" (Segundos cantos) e principalmente "Vila Maldita, cidade de Deus" (Primeiros Cantos), em que um Deus de justiça envia um cataclismo destruidor, na forma de rebelião popular (referência subjacente à Balaiada), como castigo pelas faltas humanas, mas que é seguido imediatamente de bonança e renovação. Em seu artigo "resposta a 'Religião'", parte de seu plano historiográfico publicado na revista Guanabara, a perspectiva palingenética está subjacente à noção de uma intervenção destruidora da Providência - que usa os jesuítas como instrumento para a supressão dos indígenas - e na sua confluência com uma concepção ao mesmo tempo cíclica e progressiva do tempo, que remete à metáfora do progresso, agindo "como os ponteiros de um relógio", em que o retorno não é mera reprodução do passado, mas se dá em um patamar superior, como um avanço para um futuro qualitativamente diferente. ${ }^{39}$

Por fim, mesmo em romances de José de Alencar a noção parece se fazer presente, ainda que um tanto diluída pela tendência do autor a mitigar o tratamento do sofrimento inerente ao cataclismo. 0 exemplo maior estaria no epílogo de 0 Guarani, onde Alencar dramatiza a lenda indígena de Tamandaré, o herói fundador da humanidade que sobrevive ao dilúvio no alto de uma palmeira. A cena final do romance representaria o fim do ciclo da sociedade indígena pela conjunção cataclísmica de duas forças de violência, uma social (rebelião aimoré) e outra natural (a cheia do Paquequer, que faz as vezes de dilúvio). Esse fim catastrófico é metaforicamente apresentado como a condição para a abertura de um futuro renovado, representado no voto esperançoso "Tu viverás", que um Peri já cristianizado 
40

BOSI, Alfredo. Um mito sacrificial: o indianismo de Alencar. In: Dialética da colonização. São Paulo: Cia. das Letras; 1992. Sobre a presença do mito sacrificial em Gonçalves de Magalhães ver PUNTONI, Pedro. Op. Cit. Em Macedo, ele aparece em sua peça Cobé [1854], ver TREECE, David. Op. Cit., p.214-217.

41

Ainda que, para Koselleck, a experiência não possa ser transformada tranquilamente em expectativa, o processo de definição de um horizonte de expectativa necessita de uma avaliação do campo de experiência, mas a ele não se reduz completamente. KOSELLECK, Reinhart. Op. Cit., p.313.

42

M. "Sobre a religião no Brasil em relação com os Estados Unidos, França e Inglaterra". Jornal dos Debates Políticos e Literários, Rio de Janeiro, n.12, 10/06/1837.

43

MAGALHAES, D. J. Gonçalves de. "Filosofia da religião. Sua relação com a moral e sua missão social." Nitheroy, Paris, n.2, 1836. p.32. profere a Ceci quando refugiados na copa da palmeira. Aí o casal é apresentado simbolicamente como célula de uma nova sociedade - a sociedade nacional brasileira - renovada pelo amor e fidelidade incondicional do "escravo" a sua senhora.

No geral, a presença de um paradigma palingenético no ambiente cultural de início do séc. XIX auxilia a compreender a centralidade que a questão do sacrificio desempenhou em nosso romantismo, principalmente no indianismo, tema sobre o qual não podemos nos estender. Muito além do mito fundador alencariano, identificado por Alfredo Bosi, o tema sacrificial também esteve presente em Gonçalves de Magalhães, Joaquim Manoel de Macedo e até em Gonçalves Dias, ainda que de formas e intensidades diferentes, que ainda deverão ser comprovadas por estudos específicos. ${ }^{40}$

Mas esses são desdobramentos posteriores, que não devem nos distanciar das reflexões de finais da década de 1830. Cabe, agora, indagarmos sobre os caminhos da "regeneração", a natureza dessa expectativa reaberta pela teoria da palingenesia social, ponto central para definição de um programa romântico para a nação.

O horizonte de expectativa romântico: um Brasil religioso e moral Em meio a seu uso da história em busca de alternativas para a crise pela qual passava o Brasil, Magalhães procurava inserir nosso estado de "decomposição" no quadro maior do movimento da história que animava as nações modernas. Somente pela comparação com as "nações civilizadas", pela avaliação presente de suas experiências passadas, seria possivel compreender onde estávamos e, principalmente, para onde deveriamos ir. ${ }^{41}$ Tendo como pressuposto estarem as várias nações em estágios diferentes de um mesmo movimento progressivo da Humanidade, o autor partia novamente para a comparação do estado contemporâneo do Brasil com o da França, da Inglaterra e dos EUA, então tomados como representantes do estágio mais avançado da civilização. Evidenciava-se, então, um claro descompasso:

\footnotetext{
0 Brasil, entretanto, marcha em linha diametralmente oposta [à daqueles países], e parece mesmo recuar debaixo de certo ponto de vista. Ele nada mais faz do que representar na América a França do séc. XVIII, e reproduzir de todos os modos as falsas e repulsivas doutrinas que arrastaram aquele belo país a uma revolução espantosa, e à sua completa desorganização. Dai provêm a licença, a dissolução de costumes, o egoísmo, as personalidades, e a completa abnegação para as coisas religiosas, e a falta de entusiasmo pelos negócios pátrios. Entretanto, que espetáculo diverso apresentam nossos conterrâneos do Norte. ${ }^{42}$
}

Considerando o Brasil como um caso claro de contemporaneidade do não contemporâneo, uma ilha de ceticismo setecentista em pleno séc. XIX recristianizado, Magalhães reforçava a noção de um atraso nacional que já havia apresentado no ano anterior em artigo na revista Nitheroy. ${ }^{43}$ Mas o dado novo era que ao invés de termos avançado no sentido de superar o fosso temporal que nos separava das nações mais civilizadas, o movimento parecia ter sido o exato contrário: regredíramos, agravando ainda mais nosso atraso, em uma aceleração às avessas. Acredito que o tom catastrófico empregado não se devesse somente à continuidade da crise social e política mas também contivesse, apesar de não se esgotar nele, certo cálculo político-partidário, visto que o Jornal dos Debates, em que se publicavam esses textos, tinha como objetivo declarado a derrubada 
44

M. "Sobre a religião no Brasil em relação com os Estados Unidos, França e Inglaterra". Op. Cit.

"Interior, Programa. Crise politica do Brasil". Jornal dos Debates Políticos e Literários, Rio de Janeiro, n.50, 11/01/1838. de Feijó da regência, papel ao qual o próprio Magalhães se dedicou com afinco. Nesse sentido, indicava-se que a manutenção do status quo governamental nos levaria inexoravelmente a uma "revolução espantosa", que cabia impedir.

Mas o interessante é que o trecho nos indica, por contraste, qual era o futuro ideal que do presente se projetava para o Brasil. Mesmo que a avaliação de Gonçalves de Magalhães tenha variado sobre qual o status temporal da nação, conforme vimos, ou mesmo tenha chegado a duvidar da possibilidade de um futuro, ele parecia ter clareza de para onde deveriamos caminhar, sobre qual era o fim último a que se destinava a marcha da civilização, a ser acompanhada pelo Brasil. Como o próprio texto citado deixa claro, os paises na dianteira da humanidade passavam por um processo claro de ressurgimento religioso:
A Inglaterra, a França e os Estados Unidos mostram, hoje, uma tendência nimiamente religiosa, e não uma tendência parcial neste, ou naquele elemento da civilização, mas em todos igualmente; as ciências sociais, a poesia, e as artes marcham de comum acordo para a grande obra de regeneração do gênero humano, para sua perfectibilidade moral, sua elevação à Divindade, e a todas as ideias sublimes que fazem palpitar o coração do homem cheio de entusiasmo por tudo que é santo, nobre, e grande. ${ }^{44}$

Descortina-se, claramente, o horizonte de expectativa que iluminava Magalhães e que, em graus diferentes, a serem precisados, foi compartilhado por vários membros da primeira geração de românticos brasileiros. 0 futuro almejado para a nação correspondia a uma "elevação à Divindade", representado pela retomada dos valores religiosos, entendidos, conforme veremos, como meio de estabilização social e condição para um governo livre.

Esse futuro projetado de um estágio de civilização eminentemente cristão lançava luz sobre a compreensão da crise presente. Em contraste com os paises civilizados em franca elevação moral, o estado de decomposição por que passava o Brasil era resultado de uma transformação no universo das ideias. A crise brasileira seria essencialmente marcada por uma dinâmica idealista, uma vez que "a alteração das crenças, dos sentimentos, das ideias é a causa senão única, ao menos a principal, das épocas críticas. Quando o estado moral se perverte, a sociedade não pode continuar a subsistir sem experimentar uma transformação"45. E a perversão moral do Brasil tinha como fator principal a predominância de uma moral egoista que levava ao ceticismo em matéria de religião, à indiferença política e à dissolução dos costumes. Deles, em última análise, decorria o estado de conflagração social, uma vez que "As desordens e insurreições que têm tido lugar nas províncias do Império não são, quanto a nós, derivadas das causas que se Ihes assignam, mas sim da desorganização total dos espíritos, da corrupção geral dos costumes, da depravação moral das ideias e dos sentimentos." 46

Esse diagnóstico, que perpassa a totalidade dos artigos do Jornal dos Debates e estará presente na análise que o autor fará, em 1847, da Balaiada, nada mais era do que a retomada, com mais vigor, diante do agravamento da guerra civil no Brasil nos anos de 1837 e 38, da avaliação já formulada pelo autor no texto "Filosofia da Religião, sua relação com a moral e sua missão social", publicado em 1836, na Nitheroy. Com a honrosa exceção de Roque Spencer Maciel de Barros, poucos estudiosos do 
47

Sobre o espiritualismo laico de Cousin, ver BENICHOU, Paul. Romantismes français...Op. Cit., p.241 e p.249.

\section{8}

Para um confronto pormenorizado desse texto com a perspectiva de Cousin, ver BARROS, Roque Spencer Maciel. Op. Cit., p.65-73. Concentrada nos aspectos estritamente filosóficos, a análise deixa de lado, contudo, o que considero o ponto mais importante do texto: a "missão social da religião".

49

Esse aspecto de um cristianismo entendido como variável no tempo seria uma das condições para a afirmação da possibilidade de síntese com os valores da razão e do liberalismo. Sob a fórmula de uma "religião progressiva", o tema foi aprofundado por um de nossos românticos, que não se identifica, na revista Guanabara. Ver X. de M. "Theorias. Fragmentos". Guanabara, Rio de janeiro, n.06, maio de 1850

50

MAGALHÃES, D. J. Gonçalves de. Filosofia da religião... Op. Cit., p.21.

51

Ibidem, p.23

52

CLEMENT, Paul. Chateaubriand. De l'ancien regime au nouveau monde: ecrits politiques. Paris: Hachette, 1987

MIRABEAU, Marquês de. L'amie des femmes ou Traité de la civilisation [1760]. Apud. BOER, Pinn den. Civilização: comparando conceitos e identidades. In: FERES Jr, João e JASMIN Marcelo (orgs). História dos conceitos: diálogos transatlânticos. Rio de Janeiro: Ed. PUC-Rio / Loyola / luperj, 2007. p.123. romantismo deram a atenção devida a esse texto que pode ser considerado um dos estruturadores do programa amplo, social inclusive, do romantismo brasileiro, a meu ver seu verdadeiro "manifesto". Nele, o autor apresentava não somente a sua visão da natureza e importância da religião, como traçava um breve diagnóstico da situação brasileira, não deixando de indicar os caminhos a serem tomados para a regeneração futura da nação.

Magalhães apresentava uma abordagem predominantemente filosófica e racional da religião, sem se orientar pela revelação ou princípios dogmáticos rígidos, o que o distancia de um enfoque característico do tradicionalismo ultrarrealista de Xavier de Maistre e De Bonald. Nesse sentido, mostrava-se fiel seguidor do espiritualismo laico ${ }^{47}$, entendido como uma sintese, um "justo meio", para usar a terminologia eclética, entre filosofia racional e cristianismo, tendencialmente liberal, conforme a orientação do ecletismo de Victor Cousin, a principal referência teórica de todo o texto, ainda que Magalhães revele um tom mais marcadamente cristão que 0 mestre francês ${ }^{48}$. Assim, sem citar a Bíblia em nenhum momento ou qualquer outra autoridade eclesiástica, Gonçalves de Magalhães considerava que as primeiras noções de Deus surgem na mente humana da percepção do contraste entre finito e infinito. Esse primeiro sentimento generalizado de infinitude permitia ao autor defender a existência de uma "religião natural", ponto importante para compreender como futuramente representaria os indígenas, sempre tão dispostos a receber a mensagem cristã. Ou seja, a religião transforma-se em uma faculdade comum a toda a humanidade, mas que estaria sujeita a variações na forma de sua manifestação, conforme o grau de civilização de cada povo. Em outros termos, Magalhães temporalizava a religião, introduzindo uma tensão entre a conservação de um núcleo constante de valores e sua manifestação variável no tempo ${ }^{49}$. Distanciando-se, porém, do ideal racional ilustrado, o autor ainda reconhecia a necessidade do mistério, zona de sombra inacessivel ao conhecimento humano, negando a pretensão do iluminismo e da ciência de tudo querer saber e explicar.

Para Magalhães, mais do que ser um traço do humano, a religião é considerada a principal condição para a civilização e com ela se confunde. Afinal, "tudo que ela [a história da humanidade] de mais extraordinário e sublime nos mostra, si não é inteiramente produzido por uma ideia religiosa, ao menos com ela se mescla"50. Nem os portentos da civilização moderna escaparam ao alcance civilizador da religião, pois "o Cristianismo, somente o Cristianismo é o fundamento da civilização moderna; foi ele quem salvou os restos da antiga, dele saiu a Filosofia, o Estado, a Moral, Moral sem exemplo (sic), a Indústria, as Artes, a Poesia (...)"51. Essa perspectiva parece lançar suas raizes na obra de François René Chateaubriand (autor sempre citado ainda que não diretamente nessa passagem), principalmente em seu 0 Gênio do Cristianismo, de 1802. Mais do que mostrar as belezas e a poesia da religião, esse livro, que buscou resgatar o catolicismo para uma França pós-revolucionária, dedicou-se a mostrar como o cristianismo civilizou a Europa e o mundo e se revelou mais propício ao desenvolvimento da liberdade..$^{52}$ Para o nosso romantismo, a obra de Chateaubriand parece ter auxiliado a redefinir o termo civilização, de seu sentido iluminista predominantemente laico, de "abrandamento dos costumes, urbanidade, polidez e conhecimentos difundidos" 53 , para um romântico, em que hiperdimensionava o caráter religioso, não de todo novo. Em alguns momentos, parece ter mesmo possibilitado a identificação entre civilização e cristianização. 
54

MAGALHÃES, D. J. Gonçalves de. Filosofia da religião... Op. Cit., p.19-20.

55

lbidem, p.20

56

M. "Sobre a religião no Brasil em relação com os Estados Unidos, França e Inglaterra". Op. Cit.

Sobre a crítica doutrinária ao sec. XVIII ver ROSANVALLON, Pierre. Le Moment Guizot. Paris: Galimard, 2003. p.143-152.

Mas o que mais nos interessa na caracterização da religião por Magalhães é exatamente a "sua relação com a moral e sua missão social", conforme o título do texto. A religião é resgatada por nosso poeta filósofo por servir de base a uma moral perene, que se baseie em valores estáveis e possa servir de orientação segura para a livre ação humana. Assim, "o fim da Religião" é apresentado como sendo o de "representar de uma maneira mais clara a ideia de Deus, como tal é ela um elemento necessário, e fundamental da sociabilidade; é a filosofia do povo, e a moral de todo o mundo. Se o homem tem direitos, o que nos parece inegável apesar das teorias dos panteístas, e céticos, tem também deveres; e o primeiro é para com Deus. $E_{1}$ com Kant, pensamos que a Religião é o complemento de todos os deveres, considerados como prescritos pela divindade." ${ }^{54}$ Base de toda noção de dever, ela, por isso, mostra-se indissociável de uma moral invariável e "pretender separar a Moral da religião é pretender dar-lhe outra base, e outra base, qualquer que ela seja, não sendo a ideia do dever em si, emanada de Deus como fonte de todas as ideias eternas, independentes da humana vontade, é falsa, arbitrária, incapaz de excitar em nós nenhum entusiasmo, e impotente para manter o equilíbrio social"55. A nossa ênfase recai sobre as últimas palavras: a finalidade precípua da religião, ainda que não a única, e o que orienta a reflexão de Magalhães, é a de atuar como fator de equilíbrio e união do edifício social. Sem a base de um laço moral sólido, que somente a religião poderia garantir, a sociedade arriscaria a cair ou no despotismo, pela ausência de limites ao arbítrio individual do soberano, ou na anarquia, pela inexistência do sentimento de dever nos cidadãos. Sem equilíbrio no edifício social, garantido pela moral do dever, é o próprio Estado, juntamente com suas instituições livres, que acaba sendo inviabilizado. Ou, nas palavras conclusivas do autor, "sejamos religiosos, e nós amaremos o nosso país, e respeitaremos as instituições livres" ${ }^{16}$. Num contexto de guerra civil, de ameaça de desagregação do todo nacional, o caráter social da moral do dever, calcada no cristianismo, assumia um papel central. Sua divulgação aparecia como a condição de qualquer projeto de construção nacional, constituindo o cerne do próprio projeto romântico, ao qual se ligariam várias temáticas de sua poesia, conforme veremos.

Dando continuidade à sua caracterização da religião, Magalhães considerava que essa centralidade civilizacional do cristianismo teria sido contestada no séc. XVIII e aqui, mais uma vez, o autor se distancia da ilustração. A busca de romper com o séc. XVIII ia muito além de uma simples oposição aos valores estéticos do paganismo classicista, sendo esse antes derivado de uma indisposição mais profunda. Magalhães reproduzia entre nós elementos da crítica do liberalismo doutrinário, do ecletismo e do romantismo francês ao "século das luzes", apresentado como um século de ceticismo religioso e materialismo destrutivo. Se, para os autores franceses, a crítica à filosofia do séc. XVIII era condição para o fechamento da revolução francesa, apresentando-a como o triunfo de ideais abstratos, sem base na realidade, que teriam levado ao terror jacobino, para Magalhães, 0 problema maior estaria na difusão de uma perniciosa "filosofia sensualista" que, valorizando exclusivamente as sensações, os sentimentos internos do homem, teria dado origem a uma "Moral do interesse", variável conforme as contingências e aberta a todas as formas de ambição e egoísmo. ${ }^{57}$

Aqui encontramos um ponto em que nosso romântico ia "na contramão da modernidade", para usar a fórmula de Michel Löwy e Robert Sayre. 
HIRSCHMAN, Albert 0. As paixões e os interesses. Argumentos políticos a favor do capitalismo antes de seu triunfo. Rio de Janeiro: Record, 2002.

59

MAGALHÃES, D. J. Gonçalves de. Filosofia da religião... Op. Cit., p.31.

60

Ibidem, p.32-33.
Ao desqualificar o interesse, mesmo o "bem entendido", como guia legítimo da ação humana, Magalhães e outros românticos posicionavam-se contrariamente à tendência de setores cada vez mais amplos do pensamento moderno de valorizar esse princípio. Segundo a tese de Albert Hirschman, no séc. XVIII, já entendido como "amor pelo ganho", o interesse foi apresentado, por alguns iluministas e pela nascente economia política, como o principal agente de melhoramento humano, legitimando assim o espírito aquisitivo da sociedade capitalista ${ }^{58}$. Sempre em tensão com a defesa da modernização de nossas práticas econômicas que então empreendiam, o apego à moral cristã conferia um traço antimoderno a nossos românticos, sendo também um dos esteios do antiescravismo presente na obra de Magalhães.

Não contente com articular todo o texto pela contraposição entre uma "moral do dever", de base espiritualista e cristã, e uma "moral do interesse", baseada no sensualismo dos sécs. XVII e XVIII ou no utilitarismo benthamiano, visto como o herdeiro do primeiro no séc. XIX, Magalhães procurava aplicar o quadro ao contexto brasileiro. 0 Brasil, então, era apresentado como vivendo sob a mais funesta prevalência da moral do interesse, sendo o egoísmo a causa de todos os nossos males. "Ninguém dirá certamente, que ai [Brasil] domina a Moral do dever, a Moral religiosa. A Moral livre é a única que aí se conhece, a Moral do interesse, tal como ensinara Helvetius, é a única praticada"..$^{9} 0$ resultado era o pior possivel, contaminando do governo até as artes, tornando o primeiro sem força, tornando incertos os direitos dos cidadãos, levando a reformas contínuas das leis, a um patriotismo sem sacrifício, a funcionários públicos e magistrados sem caráter elevado, a uma mocidade sem energia. ${ }^{60}$ Nos artigos do Jornal dos Debates, ela seria a chave para explicar, conforme vimos, a própria dissolução social e o estado de semimorte da nação.

Contra as interpretações que tendem a ressaltar as diferenças do "romantismo brasileiro" em relação a um "romantismo europeu" (concepção que, na prática, tende a se restringir ao caso germânico), a ponto de chegar a negar o próprio caráter romântico de nossos românticos, nada mais elucidativo que confrontar esse texto de Magalhães com o ambiente intelectual do romantismo especificamente francês, que foi aquele que mais influenciou nossos autores. Se o fizermos, tomando como referência o estudo de Paul Benichou, mais que divergências, que seguramente existiram, destacam-se as proximidades entre o nosso autor e a reflexão filosófica e politica que serviu como condição para a afirmação do romantismo francês.

Em trabalho clássico, Benichou revela como o romantismo francês nasceu de uma sintese entre uma vertente católico-legitimista e uma vertente liberal, em que ambas passaram, da década de 1800 a 1830, por um processo de transformação de seus valores, confluindo para posições semelhantes por volta de 1825, quando se fundiram na corrente romântica. Os católico-legitimistas, como Chateaubriand, Lamartine, Hugo, Ballanche, Lamenais e Vigny, dentre outros, tenderam, paulatinamente, a reconhecer alguns princípios políticos e sociais da França pós-revolucionária: as liberdades políticas, o livre debate de ideias, a noção de progresso. A vertente liberal, por sua vez, sem abdicar de sua condição de herdeira da Revolução e das luzes, passou a reconhecer a importância da religião e do cristianismo não somente como nexo indispensável para garantir o convívio pacífico e a estabilidade social, mas também como condição para 
BENICHOU, Paul. Romantismes français...Op. Cit. principalmente p.256-330.

62

ROSANVALLON, Pierre. Le Moment Guizot... Op. Cit., p.156 e p.164.

63

BENICHOU, Paul. Romantismes français...Op. Cit., p.211-250. a vigência das liberdades políticas ${ }^{61}$, processo apropriado, a seu modo, por Magalhães. Pierre Rosanvallon chega a falar de "um retorno do religioso no séc. XIX" francês, sob a crença na impossibilidade de abrir mão dos costumes (moeurs) e da religião como meios para a regulação social, uma vez que constituiam os únicos elementos de linguagem comum em contexto de intensa divisão social. ${ }^{62}$ Os principais responsáveis por essa crescente cristianização do liberalismo francês, que tomou a forma do espiritualismo filosófico, foram os intelectuais doutrinários (Royer-Collard, Prosper de Barante, Charles de Rémusat), o grupo do salão de Coppet (Madame de Staël e Benjamim Constant), os filósofos ecléticos (Victor Cousin e Theodore Jouffroy). ${ }^{63}$ Com as exceções de Chateaubriand e Kant, foi dessa corrente liberal que Magalhães tirou suas referências principais, com destaque para Cousin, Jouffroy (de quem foi aluno em Paris) e Constant, ainda que Mme de Staël somente apareça em outros artigos do Jornal dos Debates.

0 sentido tendencialmente liberal do retorno ao religioso, proposto por Magalhães, também pode ser percebido pelos meios práticos e agentes que sugeriu para a regeneração do Brasil. Nesse sentido, uma vez tornado claro o horizonte de expectativa cristão e moral que deveria orientar a superação da fase de decomposição palingenética, Magalhães conferia mais ao poeta e a uma literatura recristianizada pelo espiritualismo laico, do que propriamente a um clero restaurado, o papel de guias privilegiados da nação no processo de sua regeneração moral.

O sacerdócio laico do poeta e a invenção do intelectual brasileiro Como já indicamos, a crise por que passava o Brasil era caracterizada como sendo regida por uma dinâmica idealista. Por ela, Magalhães propunha uma relação indissolúvel entre ideias e sociedade, em que as primeiras acabavam direcionando a segunda, uma vez que:

\section{a alteração das crenças, dos sentimentos, das ideias é a causa senão única, ao menos a principal, das épocas críticas. Quando o estado moral se perverte, a sociedade não pode continuar a subsistir sem experimentar uma transformação.(...) A sociedade é a manifestação externa, a condição visivel à revelação viva e material do desenvolvimento moral do homem, da vida da alma, de suas tendências, de seus sentimentos, de suas ideias. (...) A perfeição das relações sociais é pois o reflexo brilhante, a imagem glorificada do progresso da nossa natureza íntima. ${ }^{64}$}

Dessa perspectiva para o reconhecimento da literatura como agente de transformação social e política havia somente um passo, que foi claramente transposto pelo autor. A literatura, e a poesia principalmente, não eram mero deleite estético; para Magalhães ela era principalmente 0 reflexo do "espírito da nação" e de seu grau de civilização, mas era também o meio privilegiado de agir sobre o espírito dessa nação para mudar-lhe a conformação social e política. ${ }^{65}$

Por ela, o homem poderia agir sobre a sociedade e intervir na história que, se era vista como guiada pelos planos da Providência, não deixava de ser "disponivel" em certo grau, de ter um espaço para a intervenção e livre ação do homem, uma vez que, para o poeta-filósofo, "o homem, como o povo, que não marca para si mesmo um grande destino, nunca o tem; a providência não atende a quem não quer, nem merece ser atendido"66. E, no trabalho de marcar esse destino e indicar caminhos para sua efetivação, ninguém teria mais importância do que o poeta, forma mais sublime do literato. Em artigo 
M. "Literatura Brasileira". Jornal dos Debates Políticos e Literários, Rio de Janeiro, n.43, 04/11/1837. do Jornal dos Debates, dando continuidade aos seus estudos sobre a História da literatura no Brasil, mas já direcionando o olhar para a intervenção regeneradora do literato em contextos de crise, o autor afirmava:

\begin{abstract}
Todas as revoluções são filhas das ideias; o espirito as concebe, e as opera em si, antes de as transportar ao teatro do mundo. (...) E quem será o primeiro a anunciar o novo espirito? Certamente aquele que mais capaz for de entusiasmo, e que por sua posição e linguagens mais relações tenha, e menos temido seja. Nada há mais livre que a poesia, a ela só se concedem mil generalidades, mil licenças, figuras, e imagens com o socorro das quais ela publica todas as verdades, muitas vezes sem ofender, nivela todas as condições; aos povos ensina seus direitos, prega a moral e a religião, honra suas virtudes domésticas, canta seus feitos patrióticos, mostra aos grandes e aos reis seus deveres, combate as paixões desordenadas, satiriza o vício, e constantemente levanta o homem a seu Criador, apresentando a imagem da natureza (...). ${ }^{67}$
\end{abstract}

Percebe-se como Magalhães passava a usar a própria história da literatura como meio de sondar as experiências passadas brasileiras visando indicar o caminho a se seguir no futuro. Ele apresentava antecedentes nacionais de regeneração social pela atuação de poetas (Anchieta, o principal deles), e indicava a própria missão orientadora destes. Claramente, o poeta aparecia como o condutor da nação em direção à revolução pelas ideias.

Mais uma vez, se recorrermos a Paul Benichou, perceberemos que Magalhães se empenhava em afirmar, em contexto brasileiro, aquilo que 0 crítico francês considera o próprio cerne do romantismo francês: a elevação da literatura a um grau de importância nunca antes atingido, pelo seu investimento como poder espiritual do novo século. Em outras palavras, Magalhães propunha a afirmação do sacerdócio laico do poeta. Por esse princípio, Benichou entende a compreensão por autores do início do séc. XIX de que a literatura, e a poesia em particular, viriam substituir o papel de coesão social e guia espiritual que, até o séc. XVIII, fora exercido pela religião tradicional e então passou a ser reivindicado pelo "filósofo", forma específica do intelectual iluminista voltado a difundir os valores da razão, da liberdade e da fé humanista. Porém, como resultado do "trauma" da Revolução Francesa, teria tido início o processo de julgamento e crítica do "filósofo". De Burke a Tocqueville, passando por Chateaubriand, Mme. de Stäel e Guizot, boa parte do pensamento europeu dos primeiros anos do séc. XIX, mesmo o liberal, ainda que no geral avesso à restauração da religião tradicional dogmática, identificou, como vimos, o filósofo iluminista e seus "princípios abstratos" como responsáveis pela violência jacobina e certa ameaça de dissolução social. A pura racionalidade não era entendida como capaz de despertar entusiasmo estético, empolgar, amalgamar ou disciplinar a nova sociedade.

Diante dessa avaliação, uma vertente cristã e legitimista, mas comprometida com os novos valores da liberdade e razão, representada, dentre outros, por Chateaubriand, Hugo, Ballanche e Lamartine, recusando tanto 0 modelo do clérigo tradicional quanto o do filósofo iluminista, considerava ser necessário um novo tipo de intelectual que, mantendo um caráter laico e cultor do livre pensamento, fosse capaz de dar forma a uma linguagem inspirada pelo espírito divino. Esse novo intelectual era o poeta, chamado a ser o sacerdote da nova sociedade, difusor da moral espiritualista, o guia da coletividade e profeta laico dos tempos modernos, capaz de prever os caminhos do futuro e empreender a releitura mítico-alegórica das 
BENICHOU, Paul. Romantismes français...Op. Cit., p.431-441.

69

"Quis o homem tecer os teus louvores, / E a primeira palavra foi um hino, /0 Primeiro discurso Poesia./E o homem, que té-li solto vagava, / Fraco, impotente entre animais ferozes, / Pelo místico canto atraído, /A bronca penedia abandonada/ A viver começou em sociedade."

70

M. "Literatura brasileira. Estudo sobre a história literária do Brasil". Jornal dos Debates Políticos e Literários, n.30, 16/09/1837.

71

Na definição do caráter futuro da literatura do Brasil, Magalhães indicava não somente a inspiração na natureza brasileira, mas também, e com igual importância, nos valores religiosos: "além destas materiais circunstâncias (...), um elemento há, sublime por sua natureza, poderoso por sua inspiração, variável porém quanto à sua forma, que é a base da moralidade Poética, que empluma as asas do gênio, que o abala, e o fortifica, e ao través o mundo psíquico até Deus o eleva; esse elemento é a Religião." MAGALHÃES, D. J. Gonçalves de. "Ensaio sobre a História da Literatura no Brasil". Nitheroy, Paris, vol.1, 1836, p.148.

72

M. "Embarque da expedição para o Rio Grande". Jornal dos Debates Políticos e Literários, n.36, $11 / 10 / 1837$

73

M. "pede-se a inserção do seguinte". Jornal dos Debates Políticos e Literários, Rio de Janeiro. n.37, $11 / 10 / 1837$. experiências passadas da nação, representadas principalmente na forma de poesia épica. ${ }^{68}$

Sob esse ponto de vista, torna-se mais claro o papel programático representado pela coletânea de poemas de Magalhães Suspiros Poéticos e Saudades, de 1836. A primeira experiência de elaboração de uma poesia romântica brasileira, curiosamente, quase desprezava o elemento propriamente nacionalista - descrição da cor local, da natureza e personagens brasileiros (chega a repreender Caldas por cantar o homem selvagem!) normalmente o mais ressaltado pela história literária. Mas tudo indica que, para Magalhães, para consolidar a própria função orientadora do poeta era mais do que necessário ressaltar o novo espírito cristão e sua relação indissociável com a poesia. Pontos esses presentes tanto no poema "A Poesia" (em que esta é definida como "imagem do eterno") quanto em "O vate" e "O Cristianismo, na Catedral de Milão", em que aparece explícita a teoria que identificava na poesia a linguagem característica da primeira manifestação da religião entre os povos e condição para sua vida em sociedade. ${ }^{69} \dot{A}$ luz do agravamento das revoltas regenciais, em artigo de 1837, esse papel moralista da poesia teria reforçada sua finalidade social e pacificadora, afirmando que "A Poesia é a harmonia das ideias e das palavras, é a voz misteriosa, símbolo da sociedade, é a linguagem da natureza, que atrai os homens, e a ferocidade lhes doma"70.

Magalhães esforçava-se por consolidar a legitimidade da atividade literária, recorrendo a uma missão social "pacificadora" que incorporava e ultrapassava o aspecto de construir uma imagem nacional. Para esse fim, apresentava no poeta/literato um novo modelo de intelectual brasileiro, com uma forma clara de engajamento, voltado a uma incontornável intervenção na esfera pública. Ele seria um novo Orfeu que construiria a nação, não somente pela criação de uma autoconsciência do país pela representação literária de sua natureza e costumes, mas também, e esse é o dado a se frisar, pela "pacificação" social proporcionada pela estetização e ampla difusão dos valores cristãos, esteio de uma moral do dever. ${ }^{71}$

Mas se 0 vate investia prioritariamente na criação e difusão de uma poesia moral e religiosa, carro-chefe de uma cultura da ordem, também não deixava de elogiar as iniciativas governamentais de direta repressão aos rebeldes. Novamente, artigos do Jornal dos Debates lançam luz sobre sua posição a esse respeito. Apesar de não poder ser identificado de forma rápida e simplista como um dos regressistas, em outubro de 1837, MagaIhães deles se aproximou ao elogiar o empenho do novo gabinete de Araujo Lima por tomar iniciativa imediata de enviar mais tropas ao Rio Grande do Sul. Não somente louvava a política de força do novo ministério como um renascimento, mas também tecia encômios aos soldados. ${ }^{72}$

Em outra publicação, uma curiosa e curta nota, Magalhães excepcionalmente se imiscuía em um assunto bem preciso, fora de sua alçada normal de interesses. Nele, buscava rebater críticas de Justiniano José da Rocha, do jornal 0 Cronista, à inutilidade do corpo de permanentes, que levaria à sobrecarga de atividades para a guarda nacional. Magalhães saía em defesa do corpo de permanentes, que então exerciam o papel de polícia na cidade do Rio, ressaltando os relevantes trabalhos realizados e as difíceis condições em que o realizavam. Terminava defendendo a necessidade de firmar a unidade entre todas as forças da ordem. ${ }^{73}$ Porém, 0 artigo mais nos interessa por aquilo que ele não diz, exatamente por ser indício de proximidade entre Magalhães e o então comandante do corpo 
SOUZA, Adriana Barreto de. Duque de Caxias. 0 homem por trás do monumento. Rio de Janeiro: Civilização brasileira, 2008. p.257-262.

75 BARROS, Roque S. M. de. Op. Cit., p.113. de permanentes, ninguém menos que Luiz Alves de Lima, o futuro Duque de Caxias. Ao defender os permanentes, o poeta participava, ainda que timidamente, do processo de consagração de seu comandante, que então somente se iniciava (em 1837), e que levaria à sua escolha como o líder máximo da repressão às revoltas regenciais, como mostra Adriana Barreto de Souza. ${ }^{74}$

Os artigos do Jornal dos Debates, assim, lançam luz sobre os caminhos que levaram o poeta Magalhães a se engajar diretamente na repressão às rebeliões regenciais, como secretário de Caxias, primeiramente no Maranhão, de 1839 a 1841, e depois no Rio Grande do Sul, de 1842 a 1846. Longe de ser uma atividade "lateral" a seu programa cultural, como deixa entender Roque Spencer M. de Barros ${ }^{75}$, o engajamento na repressão é indissociável da compreensão que fazia da missão do intelectual-poeta em tempos de guerra civil. Assim, Magalhães não somente definiu um projeto cultural para a nação, a partir da reflexão da natureza da crise social por que passava, como se engajou diretamente na anulação da guerra civil, seja pela consecução desse projeto cultural moralizador seja no auxílio direto à repressão das rebeliões. 0 ano de 1839 foi crucial para o encaminhamento de ambos. Quanto à efetivação do projeto cultural, é quando publicou os primeiros resultados de seu poema épico $A$ Confederação dos Tamoios, em que, à luz do horizonte de expectativa cristão e moralizador, buscou redefinir literariamente o espaço de experiência da nação, as forças destrutivas do passado que a assaltavam no presente. Quanto ao auxilio direto à repressão, também nesse ano, em dezembro, partiu para o Maranhão como secretário de Caxias, onde ajudaria a reprimir a Balaiada. Fazia jus ao papel do poeta como "arcanjo da justiça eterna!", que "Lamina acesa, fulminante empunha", fosse essa lâmina o sabre ou a pena. Para Magalhães, a pena e o sabre seriam instrumentos complementares de trazer ordem ao Império conflagrado.

\section{Considerações finais}

Em 1850, no texto programático que abria o primeiro volume da revista Guanabara, avaliava-se o presente e congratulava-se por haver "(...) tendências manifestas no espírito da nova geração para as ideias arquetipas (sic), para um futuro que há de contrastar com esses tempos do eu, do terrivel eu, que é o ponto central do círculo acanhado das gerações que tateiam entre a decadência e a imobilidade rotineira." E quando "a geração que nasceu em 1825 tomar posse da alta administração, e o Soberano governar com os homens de sua idade", (...) "Então seremos uma nação na América, porque teremos uma fé robusta, e com ela a indeclinável esperança que traz toda a convicção profunda, todo o amor de pátria, e todas as virtudes da razão social"76.

Percebe-se a permanência da expectativa definida precocemente por Magalhães, de um futuro ideal que contraste com o egoismo de um presente que tendia à clara degradação (ou à imobilidade). Percebe-se, também, o quanto era compartilhada e renitente a consciência de que a efetivação desse futuro ideal se daria pela identificação entre a consolidação da nação e a afirmação de uma "fé robusta", esteio da esperança, do amor de pátria e das virtudes sociais.

Mais do que o momento da Independência, remotamente vivenciado por alguns românticos, o periodo Regencial parece ter servido de contexto preciso para a formação do movimento romântico brasileiro. Em certo sen- 
"0 caráter dos primeiros vinte anos da literatura romântica indianista, de 1835 em diante, encontra-se inequivocamente moldado por esse clima de conflito, instabilidade e desintegração federal". TREECE, David. Exilados, aliados, rebeldes... Op. Cit., p.119.

78

Baseando-se na elaboração anterior de Dilthey e Manheim sobre a noção, autores como Michel Winock e François Sirinelli tendem a considerar uma geração, antes de tudo, pela centralidade conferida a um acontecimento marcante.

Esse assume um caráter fundador, na medida em que seu impacto na vida dos agentes é suficientemente grande para definir as questões centrais que orientarão a reflexão e produção de todo o grupo e cristalizar a sua memória coletiva. Confere-Ihe, assim, certa organicidade que, no entanto, não implica homogeneidade, uma vez que as respostas à questão variarão entre os membros do grupo. WINOCK, Pierre. Les générations intellectuelles. Vingtième Siècle, Revue d'Histoire, vol.22, 1989. Disponivel em: http://www.persee.fr/web/revues/home/prescript/ article/xxs_0294-1759_1989_num_22_1_2124? Prescripts_Search_isPortletOuvrage $=$ false (consultado em janeiro de 2010). SIRINELLI, Jean Frençois. Os intelectuais. In: RÉMOND, René (org) Por uma História política. Rio de Janeiro: Ed. da FGV; 2003.

79

Uma vez que é consagrado e de uso frequente pela historiografia, mantenho o termo. Alerto, porém, para o fato de incorporar as rebeliões da década de 1840, já fora da Regência, e não tomar esse período essencialmente pela turbulência social e política.

80

Além dos prognósticos apocalipticos onipresentes em sua obra poética, do qual o texto Meditação é a forma mais acabada, podemos encontrar cartas em que explicita seus receios. Analisando o embate político interno em Pernambuco, afirmava "Amo o Brasil como quem mais o ama, e a perspectiva de uma revolução, ainda empreendida com forças e recursos diminutos, aterra-me." DIAS, Gonçalves. Correspondência ativa de Gonçalves Dias. Anais da Biblioteca Nacional, Rio de Janeiro, vol.84, 1964. Carta 50, provavelmente de 1847, p.102. tido, e seguindo indicações de David Treece ${ }^{77}$ e a reflexão de certa história dos intelectuais francesa sobre a noção de geração $0^{78}$, talvez estudos mais aprofundados nos permitam considerar que a primeira geração romântica, articulada do final dos anos 1830 até meados dos anos 1850, em torno dos fundadores da Nitheroy e de seus seguidores Jornal dos Debates Politicos e Literários, Minerva Brasiliense e Guanabara, caracterizou-se como uma geração da guerra civil.

Esse primeiro núcleo de nossos intelectuais românticos parece ter sido fortemente marcado por um engajamento social e político, em que buscavam conciliar a implantação de instituições liberais, com a manutenção da ordem social e da unidade do Império, o que os levou a se concentrarem no tratamento e valorização do tripé representado pelas noções de liberdade, ordem social e unidade, que se fundiram em um próprio projeto de construção nacional. Vale considerar que a ênfase dada ao tratamento de cada um desses valores foi diferenciada no interior do grupo, cada autor dando mais importância para uma das pernas do tripé em detrimento da outra. Mas as análises até hoje feitas tendem a valorizar os aspectos da unidade nacional e algumas vezes da liberdade, quase nunca realizando um tratamento balizado da preocupação desses autores com a ordem social, ponto aqui privilegiado. As "rebeliões regenciais", na falta de termo melhor ${ }^{79}$, desempenhariam o papel de evento marcante, fundador de uma geração intelectual definida pela preocupação constante em construir a nação mediante a prevenção da guerra civil, ponto no qual deixavam de ser "vacilantes". Ainda que o temor da "hidra da anarquia" não seja apanágio do período regencial, os eventos dos anos 1830 e 40 conferiram um caráter de urgência a seu tratamento que não encontra paralelo no oitocentos brasileiro.

A crença de que o Brasil era uma nação em crise, à beira da dissolução, seria uma constante entre nossos românticos, estando presente mesmo no mais liberal e crítico deles, Gonçalves Dias. ${ }^{80}$ Diante do temor do conflito social, a dimensão religiosa e moral do nosso romantismo merece ter sua centralidade reconhecida novamente e seu sentido reavaliado. Mais do que traço estético e filosófico importado do romantismo francês - que não deixava de ser - ou uma idiossincrasia de Gonçalves de Magalhães, ela visava responder a questões de um contexto social brasileiro de excruciante concretude, transformando-se, assim, em esteio de uma cultura da ordem a ser implementada pelos nossos românticos. Sob esse ponto de vista, o combate ao "lusitanismo", tão frisado pela história literária, era menos importante que a luta contra o "inimigo interno" representado pelo sensualismo das luzes e seus corolários materialistas e individualistas, entendidos como fatores efetivos de dissolução da ordem social. Construir a nação, para os românticos, ia muito além da difusão de um genérico "antilusitanismo". Primordialmente, implicava construir uma imagem unificada de Brasil que incutisse valores morais e cristãos, que servissem como poder espiritual capaz de unificar o todo social. A moral religiosa espiritualista, estetizada e difundida pelo poeta, seria o meio para construir o fim almejado do Brasil como uma nação "elevada à Divindade". 